\title{
Identification of Persistent Sulfidogenic Bacteria in Shale Gas Produced Waters
}

\author{
LISA CLIFFE $^{1 *}$, SOPHIE L. NIXON ${ }^{1}$, REBECCA A. DALY ${ }^{2}$, \\ BOB EDEN $^{3}$, KEVIN G. TAYLOR ${ }^{1}$, CHRISTOPHER \\ BOOTHMAN $^{1}$, MICHAEL J. WILKINS ${ }^{2}$, KELLY C. \\ WRIGHTON $^{2}$, JONATHAN R. LLOYD ${ }^{1}$
}

${ }^{1}$ Department of Earth and Environmental Sciences, The University of Manchester, Manchester, United Kingdom. (*correspondence: Lisa.Cliffe@manchester.ac.uk)

2 Department of Soil and Crop Sciences, College of Agricultural Sciences, Colorado State University, Fort Collins, CO, United States.

${ }^{3}$ Rawwater Engineering Company Limited, Culcheth, United Kingdom.

Shale gas is considered to be the cleanest of the fossil fuels and its increased production is set to continue. Production of shale gas is made feasible by advances in horizontal drilling and hydraulic fracturing technology. Produced waters from hydraulically fractured shale formations give insight into the microbial ecology and biogeochemical conditions down-well. This study explores the potential for sulfide production by persistent microorganisms recovered from aged produced water samples collected from the Marcellus shale formation, West Virginia, USA.

Hydrogen sulfide is highly toxic and corrosive and can lead to the formation of "sour gas" which is costly to refine. Furthermore, microbial colonization of hydraulically fractured shale could result in formation plugging and a reduction in well productivity. It is vital to assess the potential for sulfide production in persistent microbial taxa, especially when considering the trend of reusing produced waters as input fluids, potentially enriching for problematic microorganisms. Using most probable number counts and 16S rRNA gene sequencing, multiple viable strains of bacteria were identified from aged produced waters, some of which produced sulfide when supplied with thiosulfate.

These results demonstrate that sulfidogenic produced water populations remain viable for years post production and, if left unchecked, have the potential to lead to natural gas souring during shale gas extraction. Further work is being conducted to assess the metabolism of key persistent bacteria in fracturing fluid formulations and their potential to form biofilms in fracture networks. 